\title{
Resolving candidate genes of mouse skeletal muscle QTL via RNA-Seq and expression network analyses
}

Arimantas Lionikas ${ }^{1 *}$, Caroline Meharg ${ }^{2,3}$, Jonathan MJ Derry ${ }^{4}$, Aivaras Ratkevicius ${ }^{1}$, Andrew M Carroll', David J Vandenbergh ${ }^{5,6}$ and David A Blizard ${ }^{7}$

\begin{abstract}
Background: We have recently identified a number of Quantitative Trait Loci (QTL) contributing to the 2-fold muscle weight difference between the LG/J and SM/J mouse strains and refined their confidence intervals. To facilitate nomination of the candidate genes responsible for these differences we examined the transcriptome of the tibialis anterior (TA) muscle of each strain by RNA-Seq.

Results: 13,726 genes were expressed in mouse skeletal muscle. Intersection of a set of 1061 differentially expressed transcripts with a mouse muscle Bayesian Network identified a coherent set of differentially expressed genes that we term the LG/J and SM/J Regulatory Network (LSRN). The integration of the QTL, transcriptome and the network analyses identified eight key drivers of the LSRN (Kdr, Plbd1, Mgp, Fah, Prss23, 2310014F06Rik, Grtp1, Stk10) residing within five QTL regions, which were either polymorphic or differentially expressed between the two strains and are strong candidates for quantitative trait genes (QTGs) underlying muscle mass. The insight gained from network analysis including the ability to make testable predictions is illustrated by annotating the LSRN with knowledge-based signatures and showing that the SM/J state of the network corresponds to a more oxidative state. We validated this prediction by $\mathrm{NADH}$ tetrazolium reductase staining in the TA muscle revealing higher oxidative potential of the SM/J compared to the LG/J strain $(p<0.03)$.
\end{abstract}

Conclusion: Thus, integration of fine resolution QTL mapping, RNA-Seq transcriptome information and mouse muscle Bayesian Network analysis provides a novel and unbiased strategy for nomination of muscle QTGs.

Keywords: Functional genomics, QTL, Skeletal muscle, Gene expression

\section{Background}

The aim of functional genomics is to understand the role of specific genes in phenotypic variation. The forward genetics approach has led to a large number of identified genomic regions, known as quantitative trait loci (QTL), influencing various phenotypes, including those for muscle weight [1-4]. However, a bottle neck has developed in the transition from QTL to their causative quantitative trait genes (QTG) [5]. Advanced intercross line strategy permits accumulation of recombinations and improves resolution of QTL mapping [6], which in the case of

\footnotetext{
* Correspondence: a.lionikas@abdn.ac.uk

${ }^{1}$ School of Medical Sciences, University of Aberdeen, Aberdeen AB25 2ZD, UK

Full list of author information is available at the end of the article
}

muscle weight has led to major reduction in confidence intervals [1]. Although appreciably refined, these QTL still harbour a number of genes. Thus, further efforts are needed to identify the QTGs that are the causative factors in complex traits.

It has been proposed that testing for the expression differences could identify genes underlying phenotypic differences [7]. Implementation of such strategy led to several nominations of QTG's [8,9]. However, microarray technology, used as a tool for a high throughput expression analyses, has several limitations which might have interfered with a more productive contribution of this approach to the nomination of the candidate genes. Hybridization artefacts caused by SNP's [10], non linearity among probes, inability to detect splice variants and,

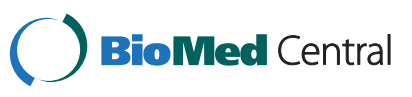


importantly, the bias towards available information (i.e. only transcripts with corresponding probes on microarray can be examined), limit the utility of expression microarrays. Transcriptome analyses by means of a massive parallel sequencing technology, RNA-Seq, circumvents the above-mentioned limitations [11,12], it is highly replicable [13] and therefore a very attractive research method for an unbiased identification of differentially expressed genes.

Our QTL studies focused on muscle size, which is an important variable influencing health and quality of life particularly in the elderly which are affected by sarcopenia, age-related muscle wasting [14]. In addition, skeletal muscle tissue is a major component of diet and a source of nutrients for the growing population of the planet. Genetic variation plays a substantial role in determining muscle size in mammals $[1-4,15,16]$ but the underlying genes remain largely unknown. Muscle mass is a function of the number and size of its fibers. The number of fibers in mouse is determined prenatally and remains stable throughout adulthood [17], whereas cross sectional area (CSA) of the fibres increases during postnatal development [18].

The LG/J and SM/J strains, which were selected for large and small body weight, respectively, in order to study processes related to growth $[19,20]$, is a promising model system for exploration of the genetic effects on muscle mass. These strains differ prominently in mass of several hind limb muscles (2-fold difference between them) and 22 QTL contributing to this difference were mapped [1]. Subsequent analyses of the soleus muscle found that the number of fibres in the muscle of the two strains was similar, whereas CSA differed substantially, $\mathrm{LG} / \mathrm{J}>\mathrm{SM} / \mathrm{J}[21]$.

The phenotypic differences due to genetic variation are determined by the pattern of information flow through molecular networks [22]. A mouse muscle Bayesian Network (MMBN) has been recently constructed based on genetic and gene expression data. The MMBN provides directional information about the relationship of gene expression and can be used as a tool for identification of the key drivers of gene expression signatures characterising various phenotypes [23].

The main finding of the present study is that the integration of the gene expression signature with the QTL analysis and muscle gene network data can lead to the identification of plausible QTGs underlying phenotypic differences in muscle mass.

\section{Results}

\section{Muscle weight}

The tibialis anterior (TA) muscle weight (mean of the right and left hindlimb) was $62.4 \pm 2.5 \mathrm{mg} v s 3.2 \pm 1.5 \mathrm{mg}$ for males of $L G / J$ and $S M / J$ strains, respectively (strain effect $\mathrm{p}<0.001)$, and $50.2 \pm 1.8 \mathrm{mg}$ vs $28.0 \pm 1.7 \mathrm{mg}$ $(\mathrm{p}<0.0001)$ for females. These estimates are comparable with our earlier findings at the same age [1]. A similar degree of the strain difference was observed in EDL, gastroncemius and soleus muscles [1].

\section{Global transcriptome}

Of 36,536 genes on the reference genome mm9, reads mapped to 22,630 genes (Additional file 1). To establish a threshold for the reliable detection of gene expression, we analysed Y chromosome genes in the female samples. From the Deseq analysis we noted that reads mapped to 5 out of $14 \mathrm{Y}$ chromosome genes in females of at least one strain with the highest expression value of 8.1 for Eif2s3y gene. Because expression of this gene is much more robust in male samples, 323.3, we excluded possibility of sample mixup. Therefore, we considered that values equal or below the 8.1 threshold were not reliable. Only the transcripts exceeding it in at least one strain were flagged as expressed in skeletal muscle (Additional file 1). There were 13,726 such genes and their transcripts accounted for $>99.9 \%$ of the mapped transcriptome. Expression levels differed greatly among the genes identified by these RNA-seq tests (Additional file 2); the 75 most abundantly expressed genes accounted for approximately the same fraction of the transcriptome as all remaining genes.

The differential expression of genes between the LG/J and SM/J strains was assessed using 3 different statistical methods. The most conservative method, Bayesian Negative-Binomial-Method-Likelihood normalization (Bayesian-NBML), found 577 differentially expressed genes at false discovery rate (FDR) of $\mathrm{p}<0.1$. The most liberal method, Bayesian-Poisson normalization, led to 9,086 genes at $\mathrm{p}<0.1$, whereas the Deseq procedure resulted in 1,184 genes at $\mathrm{p}<0.1$. A list of 1061 differentially expressed (DE) genes were identified by two out of three procedures. The DE genes were subjected to various further analyses.

\section{QTL - expression cross-reference}

A previous study [1] found that muscle weight differences between the LG/J and SM/J strains are affected by 22 QTL (loci Skmw21 - Skmw42) located on chromosomes $2,4,5,6,7,8$ and 11 . The cumulative genomic length of the loci was $75.5 \mathrm{Mb}$. The overlap between a gene's nomination by its presence under a QTL, and its differential expression was analysed next.

\section{Expression differences}

There were 1099 genes within the 22 QTL regions. Nearly half of them, 459, were expressed in TA muscle which is a 1.1 -fold enrichment (hypergeometric $p$ value $=0.00037$ ) of expressed genes within the QTL regions. We then crossreferenced this list of genes with $1061 \mathrm{DE}$ genes between 
the LG/J and SM/J strains (Additional file 1). This analysis identified 41 DE genes within eighteen QTL (Table 1). It represents a 1.3-fold enrichment of DE genes within QTL regions (hypergeometric $\mathrm{p}$ value $=0.018$ ) .

Analysis with DexSeq identified 319 differentially expressed exons at FDR $<0.1$ (Additional file 3), nine genes with such exons resided within QTL regions. Of those, expression of the Irak2 gene appeared to be higher in the LG/J strains across a number of exons (Table 2). To verify the prediction of the presence of different splice variants we examined the expression levels of the four reported splice variants. Transcript ENSMUST00000113024, which corresponds to the characterised spice variant Irak2c [24], was overrepresented in the LG/J strain compared to SM/J, whereas the other examined variants did not differ between the strains (Figure 1).

\section{Polymorphisms}

The allelic effect could be brought about by a different level of gene expression or by altered coding sequence. Therefore, it was important to examine the coding polymorphisms captured in the transcriptome of the two strains. A total of 7,933 (673 missense) SNPs (Additional file 4) and 150 Indels (Additional file 5) were identified between the LG/J and SM/J strains.

In the subsequent analysis we focused only on the genes residing within the $S k m w$ loci [1] . First, the Indel data were examined revealing a three nucleotide insertion (CTT) in exon 5 of alpha-kinase 3 gene, Alpk3, of the LG/J strain. Although the gene is not within the reported boundaries (which were determined as the region overlapped between the QTL of first principal component extracted from 5 different muscles and EDL weight QTL) of the Skmw33 locus (1.9 Mb proximal from the centromeric boundary) it is well within the QTL affecting weight of the EDL muscle [1].

We then analyzed the non-synonymous SNPs with the PolyPhen tool which predicts possible impact of an amino acid substitution on the structure and function of the protein. This analysis revealed that substitution of amino acids in 10 genes residing within the Skmw loci might affect the function of the proteins (Table 1). Two of those genes, $M g p$ and $K d r$, were also differentially expressed between the strains (Additional file 1).

\section{Network Analysis}

In addition to using differential expression and/or sequence differences to prioritize QTL region genes we took advantage of an independent mouse muscle Bayesian Network to identify putative regulators. The network was constructed from gene expression and genetic data from nine different mouse F2 crosses encompassing $>3,000$ mice and nine different mouse strains. The construction of mouse F2 Bayesian networks from genetic and expression data has been described elsewhere $[25,26]$. For this analysis we used muscle tissue networks constructed from nine different mouse F2 crosses including: BTBR ob/ob x B6 ob/ob (BTBRxB6ob) [27], C57BL/6J x C3H/HeJ (Bxh) [28], C57BL/6J Apoe-/- x C3H/HeJ Apoe-/- (BxHapoe) [29], C57BL/6J x A/J (Bxa JaxS) [30], C57BL/6J x 129S1/SvImJ (Bx129_JaxS), C57BL/6J x DBA/2J (BxD JaxS), C57BL/6J x DBA/2J (BxD JaxL), C57BL/6J x A/J (BxA MCI) [30] and C57BL/6J x DBA/2J (BxD PSU) [2]. We constructed both gender specific networks and combined networks where possible to generate a complete set of interactions. For the purposes of analysis we created a union of the 18 individual networks and included only nodes for which probes could be clearly mapped to high confidence genes. The resulting Mouse Muscle Bayesian Network (MMBN) consists of 19,513 individual nodes, corresponding to genes, and 75,092 edges, corresponding to associations between genes (Additional File 6).

First we explored the distribution of $\mathrm{DE}$ genes between the LG/J and SM/J strains within the network. A total of 855 DE genes mapped within the MMBN and remarkably, 405 genes mapped within a single coherent network exclusively containing differentially expressed genes (genes belonging to these networks are flagged in Additional File 1$)$. This is highly significant $(\mathrm{p}<0.001)$ we did not detect a similarly sized or larger coherent network with 1,000 randomly selected gene sets of the same size - and suggests that a large portion of the genes that are differentially expressed between the LG/J and $\mathrm{SM} / \mathrm{J}$ strains are co-ordinately regulated in mouse muscle independent of strain.

The Bayesian network is a directed network and hence can be used to predict regulators of a particular signature or gene set [31]. An algorithm has been recently developed, called Key Driver Analysis [23] that can be used to search a network for genes whose downstream children are enriched in genes of a signature of interest. We took the signature corresponding to the LG/SM DE genes that are contained within the network $(n=855)$ and ran the key driver analysis, thereby identifying 3,556 putative key drivers. Cross-reference of the 3,556 putative drivers of the differential signature with the 1099 genes in the QTL regions identified 116 genes (Additional file 7). This represents a significant 1.5-fold enrichment of the key drivers within the QTL regions (hypergeometric p value $=2.29 \mathrm{E}-6$ ).

When combined with the 49 genes identified by differential expression or polymorphism (Table 1) this generates a non-redundant list of 142 putative regulators. Eighteen of these are contained within the 405 gene coherent network and a further 80 are within 1-edge. Figure 2 shows a 545 gene network that contains the $405 \mathrm{DE}$ genes and their putative regulators; we refer to this as the LG/J and 
Table 1 The candidate genes nominated by expression difference and/or coding polymorphisms for skeletal muscle weight QTL (Skmw) affecting muscle weight between the LG/J (L) and SM/J (S) strains

\begin{tabular}{|c|c|c|c|}
\hline Gene & Chr & QTL & Type \\
\hline BC029722 & 2 & Skmw21 & $L<S$ \\
\hline Uqce & 2 & Skmw21 & $L>S$ \\
\hline Adig & 2 & Skmw22 & $L<S$ \\
\hline Ppp1r16b & 2 & Skmw22 & $L<S$ \\
\hline Fam83d & 2 & Skmw22 & $L>S$ \\
\hline Gm826 & 2 & Skmw22 & $L<S$ \\
\hline Chd6 & 2 & Skmw22 & $L>S$ \\
\hline Ras/11b & 5 & Skmw24 & $L<S$ \\
\hline$K d r$ & 5 & Skmw24 & $L<S$ L1176F \\
\hline Ppat & 5 & Skmw24 & $L>S$ \\
\hline Osbp/3 & 6 & Skmw25 & $L<S$ \\
\hline Mrp/19 & 6 & Skmw26 & $L<S$ \\
\hline Htra2 & 6 & Skmw26 & T449D \\
\hline Adamts9 & 6 & Skmw27 & P699A \\
\hline Gm15737 & 6 & Skmw27 & $L<S$ \\
\hline Rybp & 6 & Skmw28 & $L>S$ \\
\hline I17re & 6 & Skmw29 & $L>S$ \\
\hline Irak2 & 6 & Skmw29 & $L>S$ \\
\hline $\sec 13$ & 6 & Skmw29 & K87M \\
\hline Plbd1 & 6 & Skmw31 & $L<S$ \\
\hline$M g p$ & 6 & Skmw31 & $L<S$ Q55L \\
\hline Rerg & 6 & Skmw31 & $L<S$ \\
\hline Synm & 7 & Skmw32 & R946Q P835S \\
\hline Pgpep1I & 7 & Skmw32 & $L<S$ \\
\hline Mesdc2 & 7 & Skmw33 & $L<S$ \\
\hline Fah & 7 & Skmw33 & $L>S$ \\
\hline Nox4 & 7 & Skmw33 & $L<S$ \\
\hline $\operatorname{Prss} 23$ & 7 & Skmw33 & $L>S$ \\
\hline Mical2 & 7 & Skmw34 & $L>S$ \\
\hline 2310014F06Rik & 7 & Skmw34 & $L<S$ \\
\hline Arntl & 7 & Skmw34 & $L>S$ \\
\hline Fgfr2 & 7 & Skmw35 & $L>S$ \\
\hline $\operatorname{lrs} 2$ & 8 & Skmw36 & $L<S$ \\
\hline Col4al & 8 & Skmw36 & $L<S$ \\
\hline Col4a2 & 8 & Skmw36 & $L<S$ \\
\hline Lamp1 & 8 & Skmw36 & $\mathrm{R} 294 \mathrm{H}$ \\
\hline Grtp1 & 8 & Skmw36 & $L<S$ \\
\hline Adprh/1 & 8 & Skmw36 & $L>S$ \\
\hline$T f d p 1$ & 8 & Skmw36 & $\mathrm{R} 302 \mathrm{H}$ \\
\hline 2610019F03Rik & 8 & Skmw36 & $L>S$ \\
\hline Snord13 & 8 & Skmw37 & $L>S$ \\
\hline Dlcl & 8 & Skmw37 & $L<S$ \\
\hline
\end{tabular}

Table 1 The candidate genes nominated by expression difference and/or coding polymorphisms for skeletal muscle weight QTL (Skmw) affecting muscle weight between the $L G / J(L)$ and SM/J (S) strains (Continued)

\begin{tabular}{llll}
\hline Lphn1 & 8 & Skmw39 & $\mathrm{L}>\mathrm{S}$ \\
Podnl1 & 8 & Skmw39 & $\mathrm{L}>\mathrm{S}$ \\
Adcy1 & 11 & Skmw40 & $\mathrm{L}>\mathrm{S}$ \\
Tns3 & 11 & Skmw40 & T1067M \\
Rhbdf1 & 11 & Skmw42 & R42W \\
Hba-a2 & 11 & Skmw42 & $\mathrm{L}>\mathrm{S}$ \\
Stk10 & 11 & Skmw42 & $\mathrm{L}<\mathrm{S}$
\end{tabular}

Type indicates whether gene is more $(>)$ or less $(<)$ abundant, or position and swapped amino acids (substitutions in bold are more likely to affect protein function than those in regular font).

SM/J Regulatory Network (LSRN). Eight of 116 key drivers (Kdr, Plbd1, Mgp, Fah, Prss23, 2310014F06Rik, Grtp1, Stk10) residing within five QTL regions were either polymorphic or differentially expressed between the LG/J and $\mathrm{SM} / \mathrm{J}$ strains and therefore are strong candidates to explain the effects of these loci.

To explore properties of the LSRN further we carried out gene annotation enrichment analysis using two online bioinformatics tools; DAVID [32] and NextBio [32]. DAVID revealed a significant enrichment for GO-Terms relevant to muscle structure, function and bioenergetics. Indeed these GO-terms are very similar to those obtained with the full DE gene set (Table 3) suggesting that the LSRN is a relevant subset of DE genes. A complete set of DAVID analysis results is presented in Additional File 8. Aside from GO-terms related to muscle structural components analysis of the LSRN and $\mathrm{DE}$ genes identified a number of mitochondrial gene set enrichments suggesting potential metabolic difference between the LG/J and SM/J muscles. We explored this further by mining a larger set of internally curated signatures as well as those from NextBio. The most significant experiments identified through this analysis included signatures of expression in mouse quadriceps muscle subjected to AMPK and PPAR $\delta$ agonists $[33,34]$ and in gastrocnemius of mice subjected to hindlimb suspension [35]; 11.2-fold, $\mathrm{p}=3.25 \mathrm{e}-11$ and 2.2 -fold, $\mathrm{p}=4.7 \mathrm{e}-$ 17 respectively enrichment in the LSRN relative to the whole network. These treatments are known to have profound effects on the metabolic state of the muscle leading us to bolster our hypothesis that the differences between LG/J and SM/J may at least in part be due to fundamental metabolic variation; overlay of the expression differences with the TA muscle of the LG/J and $\mathrm{SM} / \mathrm{J}$ mice strongly predicts that the SM/J strain has a more oxidative profile than the LG/J strain.

This prediction was tested and confirmed by NADH tetrazolium reductase staining (Figure 3). The TA of the 
Table 2 Exon-specific DexSeq analysis of expression of Irak2 gene

\begin{tabular}{|c|c|c|c|c|c|c|c|c|c|c|}
\hline \multirow[t]{2}{*}{ DexSeq-exonID } & \multirow[t]{2}{*}{ Irak2 exon } & \multicolumn{4}{|c|}{ Normalised Mean Count comparison } & \multicolumn{5}{|c|}{ DexSeq Statistical Results } \\
\hline & & LG/J mean & $\mathrm{SM} / \mathrm{J}$ mean & $\begin{array}{l}\text { log2fold } \\
\text { (S/L) Calculated } \\
\text { from normlalised } \\
\text { mean counts }\end{array}$ & $P$ value & $\begin{array}{l}\text { Disp } \\
\text { Before } \\
\text { Sharing }\end{array}$ & $\begin{array}{l}\text { Disp } \\
\text { Fitted }\end{array}$ & dispersion & $\begin{array}{l}\text { log2 fold } \\
\text { (S/L) DexSeq } \\
\text { calculated }\end{array}$ & padjust \\
\hline E001 & 1 & 0.21 & 0 & 0 & 0.3632 & NA & NA & NA & NA & NA \\
\hline E002 & 1 & 1.26 & 1 & 0 & 0.6956 & 0 & 2.04 & 2.04 & 2.13 & 1 \\
\hline E003 & 1 & 7.24 & 9.28 & 0.35 & 0.5647 & 0.4 & 0.2 & 0.4 & 2.83 & 0 \\
\hline E004 & 2 & 13.77 & 11.67 & -0.02 & 0.9647 & 0.09 & 0.2 & 0.2 & 2.54 & 0 \\
\hline E005 & 3 & 6.33 & 3.3 & -0.57 & 0.3403 & 0.17 & 0.48 & 0.48 & 2 & 0.8 \\
\hline E006 & 4 & 0.82 & 2.22 & 1.24 & 0.0819 & 0.47 & 1.41 & 1.41 & 3.75 & 0.76 \\
\hline E007 & 4 & 10.59 & 0.49 & -4.03 & 0.0001 & 0.17 & 0.31 & 0.31 & -1.75 & 1 \\
\hline E008 & 4 & 45.28 & 3.16 & -3.48 & 0.0067 & 0.09 & 0.13 & 0.13 & -0.91 & 1 \\
\hline E009 & 5 & 51.11 & 8.5 & -2.67 & 0.0002 & 0.05 & 0.11 & 0.11 & -0.24 & 1 \\
\hline E010 & 5 & 27.25 & 3.97 & -2.53 & 0.0198 & 0.16 & 0.19 & 0.19 & -0.14 & 1 \\
\hline E011 & 6 & 18.98 & 1.62 & -2.94 & 0.017 & 0.12 & 0.23 & 0.23 & -0.51 & 1 \\
\hline E012 & 7 & 2.67 & 0.24 & -1.42 & 0.0424 & 0.3 & 1.59 & 1.59 & -1.57 & 1 \\
\hline E013 & 8 & 17.32 & 2.33 & -2.83 & 0.0019 & 0.18 & 0.21 & 0.21 & -0.32 & 1 \\
\hline E014 & 9 & 11.27 & 0.62 & -3.54 & 0.0041 & 0 & 0.41 & 0.41 & -1.42 & 1 \\
\hline E015 & 10 & 39.58 & 2.95 & -3.65 & 0.0009 & 0.06 & 0.14 & 0.14 & -1.18 & 0.69 \\
\hline E016 & 11 & 31.23 & 4.41 & -2.84 & 0.017 & 0.28 & 0.18 & 0.28 & -0.41 & 1 \\
\hline E017 & 12 & 48.16 & 9.62 & -2.4 & 0.001 & 0.03 & 0.12 & 0.12 & 0.03 & 1 \\
\hline E018 & 12 & 1.25 & 1.22 & -1 & 0.2566 & 1.07 & 1.59 & 1.59 & 1.1 & 1 \\
\hline E019 & 13 & 0.8 & 0.49 & 0 & 0.4139 & 0.14 & 3.09 & 3.09 & 1.38 & 1 \\
\hline E020 & 13 & 3.13 & 0.24 & -2.01 & 0.0004 & 0 & 1.07 & 1.07 & -1.27 & 1 \\
\hline E021 & 13 & 39.8 & 4.41 & -2.46 & 0.0021 & 0.16 & 0.13 & 0.16 & 0.06 & 1 \\
\hline
\end{tabular}

The pattern of exons with the higher expression of normalised counts in LG/J samples (bold) corresponds to Irak2c splice variant. Irak2 foldchanges calculated from normalised mean counts show overexpression of exon-bins 7-17, 20 and 21 in the Irak2 gene model which standard DexSeq analysis failed to detect. DexSeq-exonID - exon bins used by DexSeq; LG/J mean and SM/J mean - normalized count of reads per bin; Irak2 exons - Ensembl based exons, some exons were partitioned into several DexSeq bins; P-values - nominal $p$ value of t-test between the LG/J and SM/J samples.

$\mathrm{SM} / \mathrm{J}$ strain exhibited greater oxidative potential particularly in the deep portion of the muscle $(\mathrm{p}<0.03)$.

\section{Discussion}

We integrated a mouse muscle Bayesian Network and transcriptome data from the muscle of two inbred strains, LG/J and SM/J, with the results of QTL mapping of muscle weights in an advanced intercross [1] to nominate genes contributing to a 2-fold difference in muscle mass. The analyses based on three independent sources of information converged on a set of eight genes $(K d r$, Plbd1, Mgp, Fah, Prss23, 2310014F06Rik, Grtp1, Stk10) as the most likely QTGs residing within five QTL regions. An additional phenotypic analysis confirmed the predictive power of the gene network analysis.

\section{Transcriptome}

The present study identified 13,726 genes expressed in mouse skeletal muscle, which approximately doubles the number reported earlier in a microarray based study
[36]. An expansion of the muscle transcriptome was expected based on the recent comparison between the microarray and RNA-Seq methods in brain tissue [37], and illustrates the superior sensitivity of RNA-Seq. This set of data, therefore, provides a benchmark of expression levels of different genes within mouse muscle tissue, something that was not possible to obtain reliably with microarrays because of variation in sensitivity of hybridization among the probes [10].

The procedure of mapping of sequenced transcriptome fragments on to the reference sequence allows a defined number of mismatches [38]. This provision is particularly important for identification of polymorphisms. However, a side effect of it might be a background noise resulting from the mapping of some of the fragments (likely those originating from homologues) to the genes which in fact are not expressed in the tissue. It is possible to assess the level of such noise empirically by examining expression of the $\mathrm{Y}$ chromosome genes in females. The highest level of expression of these genes 


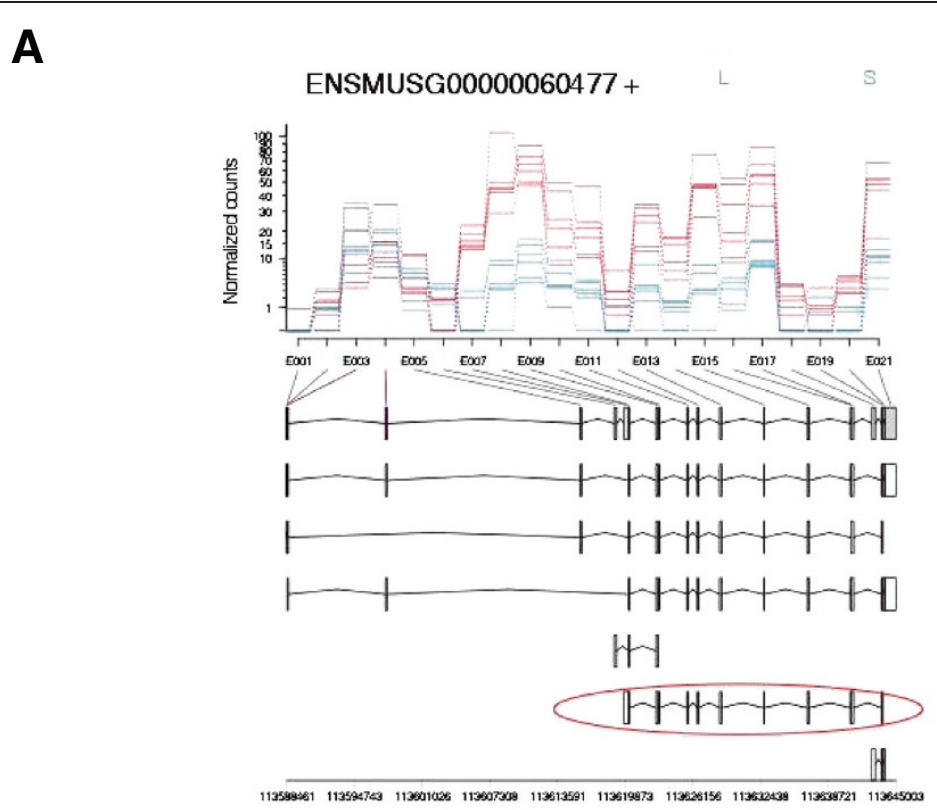

B

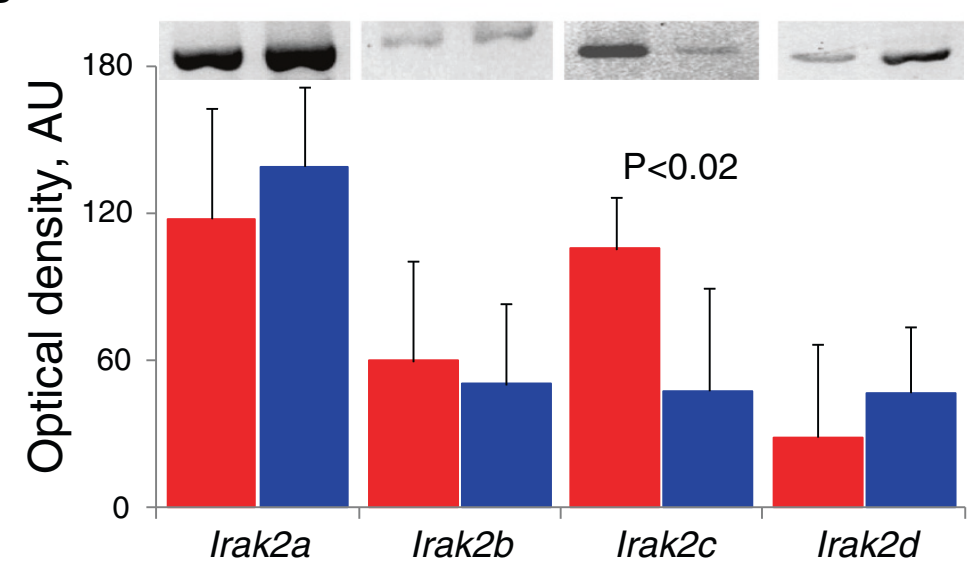

Figure 1 Splice variants of Irak2 gene in TA muscle from LG/J and SM/J strains. (A) Dexseq analysis identified differential expression of a number of exons between the LG/J (red line) and SM/J (blue line) strains. The pattern of differential expression overlapped with ENSMUST00000113024 transcript (outlined in red at the bottom) which corresponds to Irak2c splice variant [24]. (B) Abundance of the splicespecific PCR amplicones was compared between the strains (red $-L G / J$, blue $-S M / J$ ). Mean $\pm S D$ of six samples per strain (representative gels presented above corresponding bars).

found in females indicates the threshold below which a reliable assessment of transcript abundance is not possible. Application of this threshold reduced the estimated number of expressed genes by $>30 \%$.

A plethora of mouse models divergently selected for various phenotypes have been generated over the decades. These models captured increasing and decreasing alleles of relevant genes and provide a rich resource for studying of the mechanisms underlying variation in specific trait. However, as the genomic sequence of many of these strains is not available yet, utilization of these resources has been hampered. We demonstrated here that the high throughput transcriptome analysis by
RNA-Seq provides an effective way for utilizing the potential of selected strains.

\section{Validation of network analysis prediction}

The expression network analysis and integration of the information from the independent datasets provides additional leverage for prioritization of the candidate genes for further interrogation. However, it is important to assess the reliability of prediction. The analyses of gene expression data in rodent muscles indicated that expression pattern of a number of genes in the TA muscle of the SM/J strain is indicative of a more oxidative phenotype compared that of the LG/J strain. Initially 


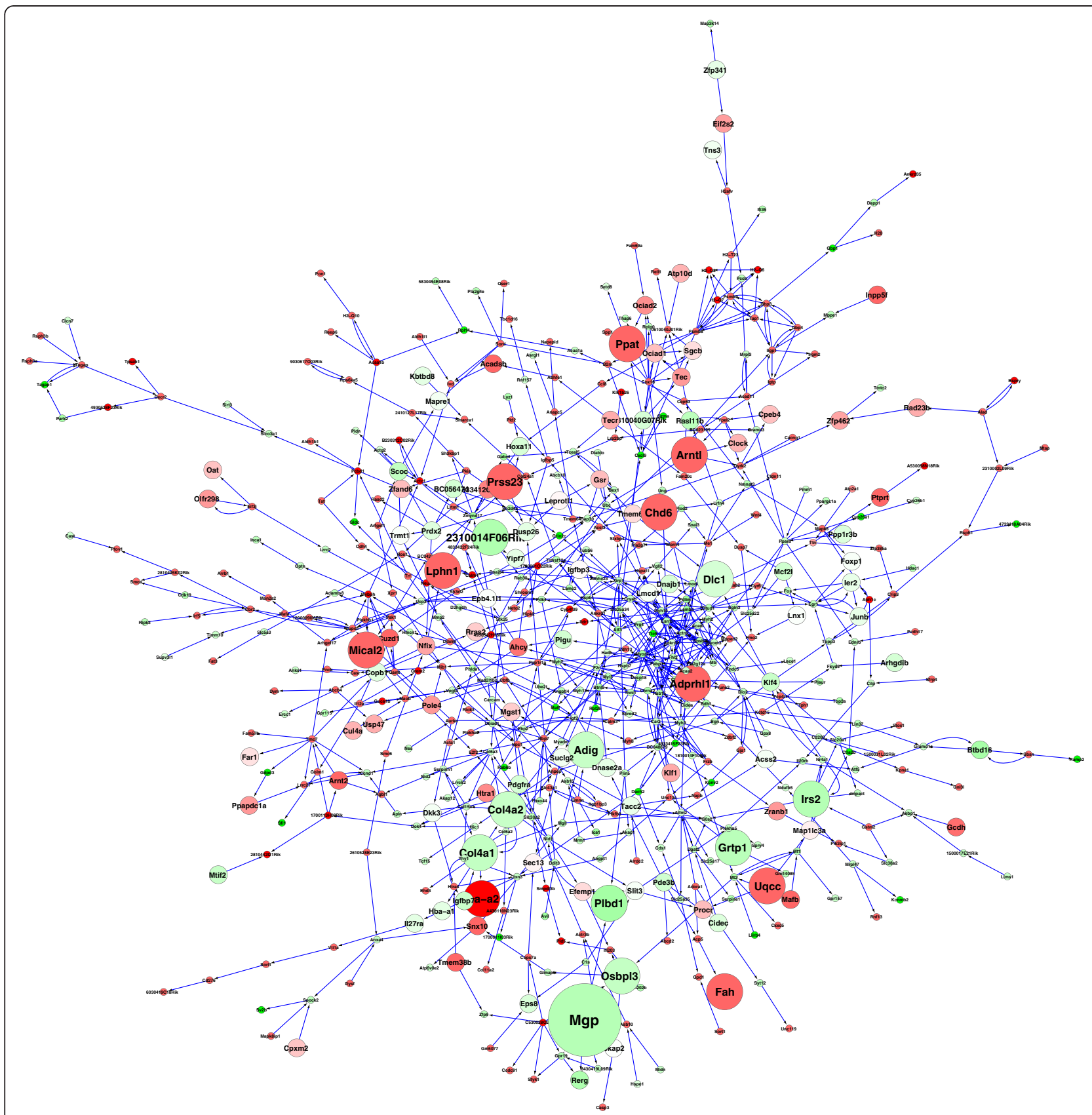

Figure 2 The 251 node network is a sub-network extracted from a large mouse muscle Bayesian network of $>19,500$ nodes using a LG/J v SM/J differentially expressed gene set of $\mathbf{7 8 1}$ genes and their putative regulators. The nodes are colored according to differential expression; red=up regulated in LG/J vs SM/J; green = down-regulated in LG/J vs SM/J. Larger nodes are matching three out of four criteria: contained in QTL critical region; predicted key driver; significantly differentially expressed; amino acid change between strains.

this appeared to conflict with our results obtained in the soleus muscle of these strains [21]. The SM/J strain exhibited lower proportion of oxidative type 1 fibers compared to the LG/J strain (e.g., in females $41 \%$ vs $58 \%$, respectively). The examination of the TA muscle however confirmed the predicted prevalence of the oxidative phenotype in the $\mathrm{SM} / \mathrm{J}$ muscle supporting the predictive power of the network analysis (Figure 3 ). The reversal of the oxidative profile between the soleus and TA muscles could be explained by the distinct composition of muscle fibers constituting these two muscles in mice; soleus is mainly composed of the fibers expressing type 1 and type 2 a myosin heavy chains, coded by Myh7 and Myh2 genes, respectively. The TA muscle, on the other hand contains very few $M y h 7$ expressing fibers but is dominated instead by the fibers expressing type $2 a, 2 x$ 
Table 3 Gene ontology (GO) terms enriched in LSRN and DE sets of genes expressed in LG/J and SM/J strain tibialis anterior muscle

\begin{tabular}{|c|c|c|c|c|c|c|c|c|c|c|c|c|}
\hline \multicolumn{3}{|c|}{ GO-Terms enriched } & \multicolumn{5}{|c|}{ DE genes } & \multicolumn{5}{|c|}{ LSRN genes } \\
\hline Category & Go-Term & Go-Description & Count & $\%$ & PValue & $\begin{array}{l}\text { Fold } \\
\text { Enrichment }\end{array}$ & Benjamini & Count & $\%$ & PValue & $\begin{array}{l}\text { Fold } \\
\text { Enrichment }\end{array}$ & Benjamini \\
\hline GOTERM_CC_FAT & GO:0043292 & $\begin{array}{l}\text { contractile } \\
\text { fiber }\end{array}$ & 18 & 1.83 & 1.87E-06 & 4.01 & $9.10 \mathrm{E}-05$ & 16 & 3.02 & 7.06E-08 & 5.88 & $6.99 \mathrm{E}-06$ \\
\hline GOTERM_CC_FAT & GO:0044449 & $\begin{array}{l}\text { contractile } \\
\text { fiber part }\end{array}$ & 17 & 1.73 & 2.20E-06 & 4.18 & $9.36 \mathrm{E}-05$ & 15 & 2.84 & 1.31E-07 & 6.09 & $9.70 \mathrm{E}-06$ \\
\hline GOTERM_CC_FAT & GO:0030016 & myofibril & 18 & 1.83 & $9.98 \mathrm{E}-07$ & 4.18 & 5.67E-05 & 16 & 3.02 & 3.89E-08 & 6.14 & $1.16 \mathrm{E}-05$ \\
\hline GOTERM_CC_FAT & GO:0044429 & $\begin{array}{l}\text { mitochondrial } \\
\text { part }\end{array}$ & 49 & 4.99 & 7.64E-06 & 1.98 & 2.61E-04 & 36 & 6.81 & $2.55 \mathrm{E}-06$ & 2.40 & 1.51E-04 \\
\hline GOTERM_CC_FAT & GO:0016460 & $\begin{array}{l}\text { myosin ॥ } \\
\text { complex }\end{array}$ & 6 & 0.61 & $1.38 \mathrm{E}-04$ & 10.58 & 3.36E-03 & 6 & 1.13 & $1.24 \mathrm{E}-05$ & 17.46 & $6.13 \mathrm{E}-04$ \\
\hline GOTERM_CC_FAT & GO:0005759 & $\begin{array}{l}\text { mitochondrial } \\
\text { matrix }\end{array}$ & 21 & 2.14 & 8.33E-05 & 2.73 & 2.36E-03 & 17 & 3.21 & $1.70 \mathrm{E}-05$ & 3.64 & $7.23 \mathrm{E}-04$ \\
\hline GOTERM_CC_FAT & GO:0031980 & $\begin{array}{l}\text { mitochondrial } \\
\text { lumen }\end{array}$ & 21 & 2.14 & 8.33E-05 & 2.73 & 2.36E-03 & 17 & 3.21 & 1.70E-05 & 3.64 & 7.23E-04 \\
\hline GOTERM_CC_FAT & GO:0032982 & $\begin{array}{l}\text { myosin } \\
\text { filament }\end{array}$ & 6 & 0.61 & 4.65E-04 & 8.46 & 9.87E-03 & 6 & 1.13 & 4.37E-05 & 13.97 & 1.62E-03 \\
\hline GOTERM_CC_FAT & GO:0016459 & $\begin{array}{l}\text { myosin } \\
\text { complex }\end{array}$ & 11 & 1.12 & $5.18 \mathrm{E}-04$ & 3.82 & 1.03E-02 & 10 & 1.89 & 5.33E-05 & 5.73 & $1.76 \mathrm{E}-03$ \\
\hline GOTERM_CC_FAT & GO:0005859 & $\begin{array}{l}\text { muscle } \\
\text { myosin } \\
\text { complex }\end{array}$ & 5 & 0.51 & $8.20 \mathrm{E}-04$ & 10.58 & $1.26 \mathrm{E}-02$ & 5 & 0.95 & $1.20 \mathrm{E}-04$ & 17.46 & $2.73 \mathrm{E}-03$ \\
\hline GOTERM_CC_FAT & GO:0005739 & mitochondrion & 94 & 9.58 & 4.62E-05 & 1.50 & 1.43E-03 & 62 & 11.72 & 1.02E-04 & 1.64 & $2.75 \mathrm{E}-03$ \\
\hline GOTERM_CC_FAT & GO:0005740 & $\begin{array}{l}\text { mitochondrial } \\
\text { envelope }\end{array}$ & 34 & 3.47 & 8.90E-04 & 1.84 & 1.31E-02 & 24 & 4.54 & 8.65E-04 & 2.14 & $1.50 \mathrm{E}-02$ \\
\hline GOTERM_MF_FAT & GO:0017076 & $\begin{array}{l}\text { purine } \\
\text { nucleotide } \\
\text { binding }\end{array}$ & 117 & 11.93 & 1.90E-04 & 1.38 & 4.57E-02 & 80 & 15.12 & $6.56 \mathrm{E}-05$ & 1.54 & $1.85 \mathrm{E}-02$ \\
\hline GOTERM_CC_FAT & GO:0005863 & $\begin{array}{l}\text { striated } \\
\text { muscle } \\
\text { thick } \\
\text { filament }\end{array}$ & 4 & 0.41 & 4.90E-03 & 10.58 & $6.24 \mathrm{E}-02$ & 4 & 0.76 & 1.16E-03 & 17.46 & $1.90 \mathrm{E}-02$ \\
\hline GOTERM_CC_FAT & GO:0044421 & $\begin{array}{l}\text { extracellular } \\
\text { region part }\end{array}$ & 65 & 6.63 & $6.92 \mathrm{E}-06$ & 1.78 & 2.62E-04 & 38 & 7.18 & $1.42 \mathrm{E}-03$ & 1.71 & 2.20E-02 \\
\hline GOTERM_CC_FAT & GO:0005743 & $\begin{array}{l}\text { mitochondrial } \\
\text { inner } \\
\text { membrane }\end{array}$ & 28 & 2.85 & 8.09E-04 & 2.00 & 1.31E-02 & 19 & 3.59 & $2.12 \mathrm{E}-03$ & 2.24 & $2.96 \mathrm{E}-02$ \\
\hline GOTERM_CC_FAT & GO:0031966 & $\begin{array}{l}\text { mitochondrial } \\
\text { membrane }\end{array}$ & 31 & 3.16 & $2.53 \mathrm{E}-03$ & 1.78 & 3.39E-02 & 22 & 4.16 & $2.04 \mathrm{E}-03$ & 2.09 & 2.98E-02 \\
\hline
\end{tabular}


A
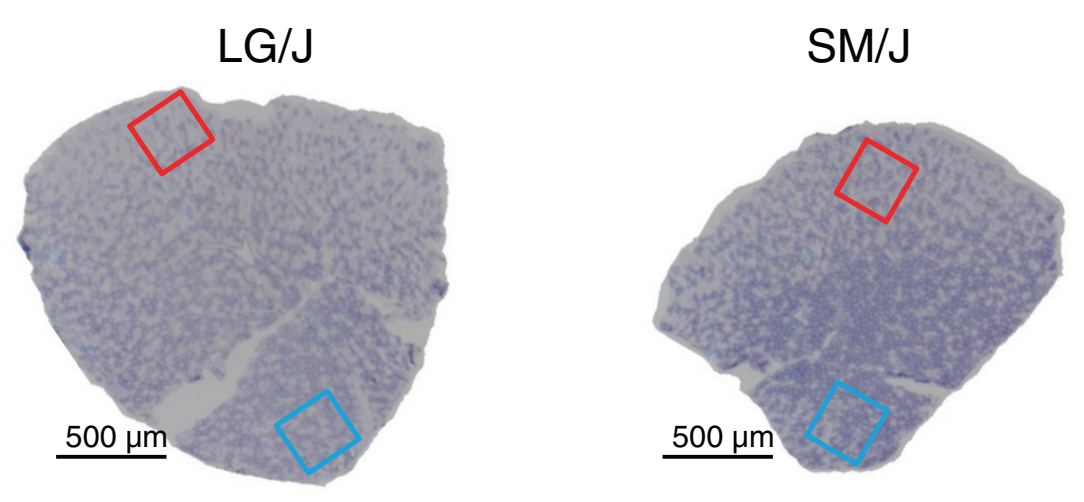

B

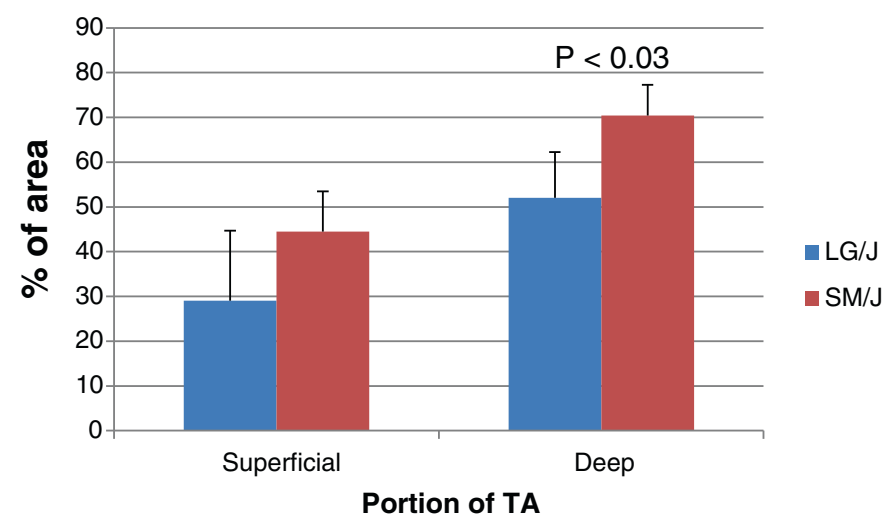

Figure 3 NADH tetrazolium reductase staining in TA muscle. Representative areas of the superficial (panel $\mathbf{A}$, red box) and deep (blue box) portion of the muscle were quantified for the staining intensity (darker stain corresponds to a higher oxidative capacity). Panel $\mathbf{B}$; mean and SD ( $n=4$ per strain) of the area occupied by the dark stained, oxidative, fibers.

(Myh1) and 2b (Myh4) myosin heavy chains [39]. From this set of data it appears that the proportion of type 1 $v s$ type $2 \mathrm{a}$ fibers in the soleus is determined by different mechanisms than the proportion of type $2 \mathrm{a}, 2 \mathrm{x}$ and $2 \mathrm{~b}$ fibers in TA muscle.

\section{Candidate genes in the QTL regions}

It has been suggested that variation in gene expression is important contributor to the genetic architecture of complex traits [7]. Integration of the gene expression profiling by microarrays and QTL screening in classical mapping populations (backcross or F2) has led to identification of QTGs underlying allergic asthma [8] and bone mineral density [9], and to nomination of the candidate genes underlying adipose tissue [40] just to mention some of the successful attempts to identify QTGs. An improvement in the mapping resolution afforded by an advanced intercross population and enhanced sensitivity of the transcriptome analysis by RNA-Seq provides further incentives for application of this strategy.

Integration of RNA-Seq data with results of QTL mapping from an advanced intercross reduced the number of positional candidates from 1099 genes residing throughout QTL regions to 49 candidate genes differentially expressed or with the coding polymorphisms (with likely functional consequences) between the two strains. These genes were spread across thirteen QTL. Three of those loci, Skmw25, Skmw26 and Skmw34, harboured only one candidate gene (Table 1). The candidacy of Htra 2 gene (Skmw26) was supported by the mnd2 model demonstrating a severe muscle wasting phenotype and abnormality of motor neurons resulting from the mutation in the gene $[41,42]$. The serine peptidase coded by Htra 2 gene is located in the mitochondrial intermembrane space. It activates proapoptotic proteins upon release into the cytosol from damaged mitochondria [43]. Interestingly, in addition to the T449D polymorphism, the transcript abundance of the gene tended to be higher in the $\mathrm{SM} / \mathrm{J}$ strain $(\mathrm{p}=0.13$; Additional file 1$)$. There is no information on the possible effects of the two genes that are located in single-gene loci (Osbpl3 in Skmw25 and 2310014F06Rik in Skmw34). The latter gene is not translated into a protein (www.ensembl.org). However, it possesses the properties of the long intergenic non- 
coding RNA, lincRNA [44], which have been implicated in such biological processes as imprinting [45] and trans-gene regulation [46].

The remaining ten loci (ranging in size from 1.2 Mb to $5.0 \mathrm{Mb}$ ) harboured 2 or 3 candidates. From these results it appears that either the trait is truly polygenic, with more than one gene contributing to a QTL even when the latter had been refined to few $\mathrm{Mb}$, or some of these genes are not causative. Validation studies will be required to address this question.

The ability of RNA-Seq to capture splice variants resulted in an interesting candidate gene for Skmw29 locus. Irak2 codes for Interleukin-1 receptor-associated kinase 2 which is involved in immune response and is important for activation of NFkB pathway. Four splice variants of the gene with antagonistic effects were identified in mouse; overexpression of Irak $2 a$ and Irak $2 b$ potentiated activation of NFkB pathway, whereas Irak $2 c$ and Irak $2 d$ variants inhibited it [24]. The overexpression of Irak2 in LG/J strain muscles compared to SM/J strain (Additional file 1) was primarily due to $\operatorname{Irak} 2 c$ as the levels of three other variants were similar (Figure 1B). It has been demonstrated that persistent activation of NFKB pathway caused muscle wasting [47]. Thus, there is a mechanistic link between the levels of expression in Irak $2 c$ and muscle mass which identifies the gene as a strong candidate to explain the effect of $S k m w 29$ locus. Overexpression of Irak2c might have contributed to larger muscle mass in LG/J strain by inhibiting NFkB activation.

The $K d r$ gene in the $S k m w 24$ locus, encodes for one of the vascular endothelial growth factor receptors and is involved in the development of skeletal muscle tissue [48]. Furthermore, it has been shown that an acute response of the skeletal muscle to resistance exercise involves upregulation of its expression [49]. Resistance exercise is a well known muscle mass increasing stimulus, thus it is plausible that the L117F polymorphism in an evolutionarily conserved region might be contributing to the muscle weight difference between the LG/J and $\mathrm{SM} / \mathrm{J}$ strains.

The gene coding for matrix GLA protein ( $M g p$, Skmw31) was shown to be a suppressor of tissue calcification [50]. Mutation of the MGP gene in humans causes Keutel syndrome [51]. A higher level of expression of this gene in skeletal muscle was associated with intramuscular fat infiltration known as marbling in cattle [52].

Several of the identified genes are involved in cell signalling (e.g. the genes coding for the regulatory inhibitor subunit 16B of protein phosphatase 1, Ppp1r16b, (Skmw22), and serine/threonine-protein kinase 10, Stk10, (Skmw42)), respond to the growth stimulus (growth hormone regulated TBC protein 1, Grtp1 [53]) or are involved in regulation of transcription (the Tfdp1 gene encodes for a transcription factor involved in regulation of the cell cycle
[54]). Thus, in addition to being differentially expressed or polymorphic these genes also represent the functional candidates which potentially can modify the abundance of muscle tissue.

In addition to the genes discussed above, the Alpk3 gene in the LG/J strain carries an insertion in exon 5 compared to the $\mathrm{SM} / \mathrm{J}$ allele. The insertion, CTT, results in additional amino acid, leucine (following the 212 position of the reference sequence), distally of the I-set domain. Functional differences between the two Alpk3 variants have not been reported.

\section{QTL lacking candidate genes}

Our approach did not suggest any robust candidates for 4 earlier identified QTL. Interestingly, some of those loci had a substantial effect size on muscle mass (i.e. Skmw23, Skmw30, Skmw38 and Skmw41). Collectively these observations imply that the underlying cause of these loci rest beyond the gene expression patterns in muscle tissue or polymorphisms within the genes. For instance, systemic factors such as hormones can affect muscle tissue. It is also conceivable that the causative genes were expressed during development which might have influenced the number of muscle fibers. In either of those instances no footprint of the influence in muscle transcriptome would be detected.

Only $\sim 4 \%$ of differentially expressed genes reside within QTL regions. This observation raises a question about the role of the remaining majority in relation to muscle mass. It can be speculated that secondary changes in gene expression pattern are triggered in the network associated with the QTL causing genes, and genes encoding transcriptional regulators are particularly good candidates. It is also plausible that the systemic factors influencing muscle size are contributing to differential expression between strains. Finally, some of these genes might be involved in other phenotypes and processes which are contrasting between the strains but which are not reflected in muscle weight (e.g. variation in proportion of different fiber types). Integration of the expression data in various tissues at different developmental stages, under different environmental conditions, and profiling of the systemic hormones and growth factors could help understanding of some relationships in gene expression patterns.

\section{Conclusions}

We presented a snapshot of the transcriptome in skeletal muscle from two mouse strains diverging in muscle mass. Furthermore, we showed that overlaying the transcriptome data with the refined genetic architecture of the trait and cross-referencing that with the gene expression network data in skeletal muscle yielded an unbiased list of candidate genes which might affect muscle mass. 
This integrative approach will facilitate the transition from QTL to detection of their underlying QTGs.

\section{Materials and methods}

The LG/J and SM/J mice (3 males and 3 females of each strain) were purchased from the Jackson laboratory. At the age of 92 days animals were sacrificed and tibialis anterior (TA) muscle was dissected bilaterally, weighed and snap-frozen in isopentane chilled with liquid nitrogen. All procedures were approved by the Institutional Animal Care and Use Committee of the Pennsylvania State University.

\section{RNA preparation}

Total RNA from the TA muscle was extracted using TRIzol (Invitrogen Life Technologies, Carlsbad, CA). Approximately $10 \mu \mathrm{g}$ of RNA from male and female samples were then submitted for transcriptome sequencing using RNASeq technology: SOLEXA/Illumina (The Gene Pool, http// genepool.bio.ed.ac.uk) or HiSeq 2000 (Genome Enterprise Limited; www.genome-enterprise.com) platforms.

\section{RNA-seq \\ Illumina/ SOLEXA GA II}

To prepare Illumina RNAseq libraries $3 \mu \mathrm{g}$ of total RNA were subjected to one round of poly-A selection on oligo (dT) (Serabeads) and resultant mRNA was fragmented to an average size of $100 \mathrm{bp}$ following manufacturer's recommended protocol (Illumina mRNAseq kits Cat no. RS100-0801). Then, 1st strand cDNA synthesis was carried out using Superscript III reverse transcriptase (Invitrogen cat no.18080051) with the modification of $3 \mu \mathrm{g}$ random primers (Illumina mRNAseq kits Cat no. RS-100-0801). The second strand cDNA and RNAseq libraries were prepared according to the manufacturer's recommended protocol (Illumina, San Diego, CA, USA). Briefly, the cDNA fragments were blunt ended, A-tailed followed by ligation of Illumina paired end oligo adapters. The adapter ligated fragments were size selected (50 nucleotides) on a $2 \%$ agarose gel, and then subjected to 18 cycles of PCR; at this stage modified indexed Illumina primers were used to introduce unique barcodes to each sample. The fragment size, and concentration of resultant libraries were assessed by Qubit (Invitrogen QuantIT HS).), and on a Bioanalyser High Sensitivity Chip. All samples were diluted to $10 \mathrm{nmol}$ in $\mathrm{EB} / 0.1 \%$ tween and were de-natured, clustered and sequenced at a density of 1/GA2X lane to yield at least $15 \mathrm{M}$ reads/sample.

\section{HiSeq2000}

The Illumina TruSeq RNA Sample preparation kit (Illumina Inc.) was used according to the manufacturer's protocol. In brief, poly-A containing mRNA molecules were purified from $0.5 \mu \mathrm{g}$ total RNA using poly-T oligo attached magnetic beads using two rounds of purification. The purified mRNA was fragmented by addition of $5 \mathrm{x}$ fragmentation buffer (Illumina, Hayward, CA) and was heated at $94^{\circ} \mathrm{C}$ in a thermocycler for 8 minutes. The fragmentation yields fragments of $\sim 250 \mathrm{bp}$. First strand cDNA was synthesised using random hexamers to eliminate the general bias towards the 3 ' end of the transcripts. Second strand cDNA synthesis was done by adding GEX second strand buffer (Illumina, Hayward, CA), dNTPs, RNaseH and DNA polymerase I followed by incubation for $2.5 \mathrm{~h}$ at $16^{\circ} \mathrm{C}$. Second strand cDNA was further subjected to end repair, A-tailing, and adapter ligation with barcoded adapters in accordance with the manufacturer supplied protocols. Purified cDNA templates were enriched by 15 cycles of PCR for $10 \mathrm{~s}$ at $98^{\circ} \mathrm{C}, 30 \mathrm{~s}$ at $60^{\circ} \mathrm{C}$, and $30 \mathrm{~s}$ at $72^{\circ} \mathrm{C}$ using PCR Primer Mix Cocktail and PCR Master Mix (Illumina, Hayward, CA). The samples were cleaned using AMPure XP Beads and eluted in $30 \mu \mathrm{l}$ Resuspension Buffer as per manufacturer's instructions (QIAGEN, CA). Purified cDNA libraries were quantified using Bioanalyzer DNA 100 Chip (Agilent Technology 2100 Bioanalyzer). The libraries were normalised to $10 \mathrm{nM}$ and pooled equimolarly in pools of 2 samples per pool.

\section{Bioinformatics}

Sequencing reads were aligned to the reference mouse genome (UCSC assembly $\mathrm{mm} 9$ ) using tophat v 1.3.1 [38] allowing 1 alignment per read and mapping to known exon-exon junctions of known Ensemble genes. The number of reads mapping to each Ensemble gene was counted with htseq (http://www-huber.embl.de/users/ anders/HTSeq/doc/overview.html). Statistical analysis was performed in $\mathrm{R}$ using the bioconductor package Deseq, based on the negative binomial distribution, with variance and mean linked by local regression [55] and baySeq, which uses an empirical Bayes approach [56]. Variant analysis was performed with samtools 0.1.14 [57], annotation of variants was performed with seqgene v 2.3 [58]. SNPs and Indels with Variant and Mapping quality $>20$ and present in all replicate samples were marked as potentially significant. Dexseq was used for analysis of differentially expressed exons, visualization and exploration for identification of differentially expressed splice variants [59]. To overcome some of the limitations of DexSeq with respect to correct identification of all differentially expressed exon-bins when many exon-bins in one gene model are affected, we used both DexSeq statistics and visualisation of normalised counts and, in addition, we calculated strain mean and fold change between strains for interpretation of the results as exemplified for Irak2 (Table 2).

The PolyPhen web based tool [60] was utilized to predict the possible effects of amino acid substitution on 
the function of a protein (http://genetics.bwh.harvard. edu/pph/). These predictions are based on multiple sequence alignments, and functional and structural characterization of the substitution site.

\section{RT PCR}

Expression of splice variants of the Irak2 gene were examined using combinations of Irak2-1 (forward, F) and Irak2-3 (reverse, R; for Irak2 $a$ and Irak $2 b$ variants), and Irak2-7 (F), Irak2-3 (R; for Irak2d) primers reported by Hardy and O'Neill [24]; and a pair of primers for Irak2c (F, 5'-GCACTGACTGAGGGAAAAGG-3'; R, 5'CCAAAAGCCTTTCTTGCTTG-3').

The RT PCR procedure has been described in detail [61]. The images of the PCR products were quantified using ImageJ software ( $\mathrm{NIH}$ - version 1.43).

\section{F2 cross data for network analyses}

Six of the nine crosses reported in this paper (BTBRxB6ob, BxH, BxHapoe, BxA_JaxS, BxA_MCI and BxD_PSU) have been previously published $[2,27,28,29,30]$. Of the remaining three crosses, two (Bx129_JaxS and BxD_JaxS) are from the same experimental design as BxA_JaxS but are from Bx129 and BxD backgrounds, respectively. The third cross, BxD_JaxL, is also a BxD background but rather than a 20 week design (JaxS) the mice were aged for 64 weeks (JaxL).

\section{Statistical analyses}

Unless otherwise stated, statistical comparisons were carried out using a t-test, and the data presented as mean \pm SD.

\section{Additional files}

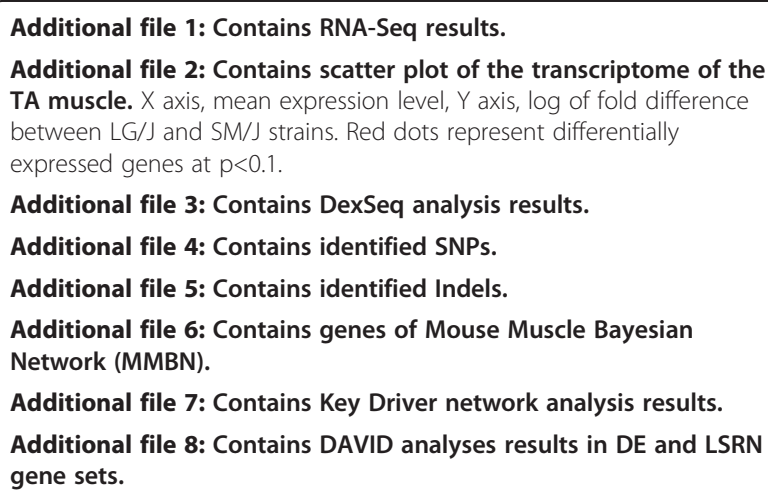

\section{Competing interests}

The authors declare that they have no competing interests.

\section{Authors' contributions}

AL conceived the study, collected phenotypes, did molecular biology and drafted the manuscript; CM carried out bioinformatics including sequence alignment, screening for SNPs, indles and splice variants and helped to draft the manuscript; JMJD made substantial contribution to design of the study, conducted network analysis, and drafted the manuscript; AR carried out molecular biology and helped drafting the manuscript; AMC carried out histology and participated in drafting of the manuscript; DJV participated in preparation of the manuscript; DAB collected phenotypes and helped drafting the manuscript. All authors read and approved the final manuscript.

\section{Acknowledgements}

Research reported in this publication was supported by the National Institute of Arthritis and Musculoskeletal and Skin Diseases of the National Institutes of Health under Award Number AR056280 (DAB). The content is solely the responsibility of the authors and does not necessarily represent the official views of the National Institutes of Health. This work was also supported by Marie Curie International Reintegration Grant 249156 (AL).

\section{Author details}

${ }^{1}$ School of Medical Sciences, University of Aberdeen, Aberdeen AB25 2ZD, UK. ${ }^{2}$ School of Medicine \& Dentistry, University of Aberdeen, Aberdeen AB25 2ZD, UK. ${ }^{3}$ Bioinformatics group, Max Planck Institute for Biology of Aging, Köln D-50931, Germany. ${ }^{4}$ Sage Bionetworks, Seattle, WA 98109, USA. ${ }^{5}$ Department of Biobehavioral Health, University Park, PA 16802, USA. ${ }^{6}$ Penn State Institute for the Neurosciences, University Park, PA 16802, USA. ${ }^{7}$ College of Health and Human Development, The Pennsylvania State University, University Park, PA 16802, USA.

Received: 20 April 2012 Accepted: 26 October 2012

Published: 5 November 2012

\section{References}

1. Lionikas A, Cheng R, Lim JE, Palmer AA, Blizard DA: Fine-mapping of muscle weight QTL in LG/J and SM/J intercrosses. Physiological Genomics 2010, 42 A(1):33-38.

2. Lionikas A, Blizard DA, Vandenbergh DJ, Glover MG, Stout JT, Vogler GP, McClearn GE, Larsson L: Genetic architecture of fast- and slow-twitch skeletal muscle weight in 200-day-old mice of the C57BL/6J and DBA/2J lineage. Physio/ Genomics 2003, 16(1):141-152.

3. Lionikas A, Blizard DA, Gerhard GS, Vandenbergh DJ, Stout JT, Vogler GP, McClearn GE, Larsson L: Genetic determinants of weight of fast- and slow-twitch skeletal muscle in 500-day-old mice of the C57BL/6J and DBA/2J lineage. Physiological Genomics 2005, 21:184-192.

4. Lionikas A, Blizard DA, Vandenbergh DJ, Stout JT, Vogler GP, McClearn GE, Larsson L: Genetic determinants of weight of fast- and slow-twitch skeletal muscles in old mice. Mammalian Genome 2006, 17(6):615-628.

5. Flint J, Valdar W, Shifman S, Mott R: Strategies for mapping and cloning quantitative trait genes in rodents. Nat Rev Genet 2005, 6(4):271-286.

6. Darvasi A, Soller M: Advanced intercross lines, an experimental population for fine genetic mapping. Genetics 1995, 141(3):1199-1207.

7. Mackay TFC: In The genetic architecture of quantitative traits. Edited by Anonymous.; 2001:303-339. Anonymous, vol 35.

8. Karp CL, Grupe A, Schadt E, Ewart SL, Keane-Moore M, Cuomo PJ, Köhl J, Wahl L, Kuperman D, Germer S, Aud D, Peltz G, Wills-Karp M: Identification of complement factor 5 as a susceptibility locus for experimental allergic asthma. Nat Immunol 2000, 1(3):221-226.

9. Klein RF, Allard J, Avnur Z, Nikolcheva T, Rotstein D, Carlos AS, Shea M, Waters RV, Belknap JK, Peltz G, Orwoll ES: Regulation of Bone Mass in Mice by the Lipoxygenase Gene Alox15. Science 2004, 303(5655):229-232.

10. Walter NA, McWeeney SK, Peters ST, Belknap JK, Hitzemann R, Buck KJ: SNPs matter: impact on detection of differential expression. Nat Methods 2007, 4(9):679-680.

11. Mortazavi A, Williams BA, McCue K, Schaeffer L, Wold B: Mapping and quantifying mammalian transcriptomes by RNA-Seq. Nat Methods 2008, 5(7):621-628.

12. Trapnell C, Williams BA, Pertea G, Mortazavi A, Kwan G, van Baren MJ, Salzberg SL, Wold BJ, Pachter L: Transcript assembly and quantification by RNA-Seq reveals unannotated transcripts and isoform switching during cell differentiation. Nat Biotechnol 2010, 28(5):511-515.

13. Marioni JC, Mason CE, Mane SM, Stephens M, Gilad Y: RNA-seq: an assessment of technical reproducibility and comparison with gene expression arrays. Genome Res 2008, 18(9):1509-1517.

14. Cruz-Jentoft AJ, Baeyens JP, Bauer JM, Boirie Y, Cederholm T, Landi F, Martin FC, Michel JP, Rolland Y, Schneider SM, Topinkova E, Vandewoude M, Zamboni M: European Working Group on Sarcopenia in Older People: Sarcopenia: European consensus on definition and diagnosis: Report of 
the European Working Group on Sarcopenia in Older People. Age Ageing 2010, 39(4):412-423.

15. Brockmann GA, Kratzsch J, Haley CS, Renne U, Schwerin M, Karle S: Single QTL effects, epistasis, and pleiotropy account for two-thirds of the phenotypic $F(2)$ variance of growth and obesity in DU6i x DBA/2 mice. Genome Res 2000, 10(12):1941-1957.

16. Masinde GL, Li X, Gu W, Hamilton-Ulland M, Mohan S, Baylink DJ: Quantitative trait loci that harbor genes regulating muscle size in (MRL/MPJ x SJL/J) F(2) mice. Funct Integr Genomics 2002, 2(3):120-125.

17. Wigston DJ, English AW: Fiber-type proportions in mammalian soleus muscle during postnatal development. J Neurobiol 1992, 23(1):61-70.

18. Wirtz $P$, Loermans HM, Peer PG, Reintjes AG: Postnatal growth and differentiation of muscle fibres in the mouse. I. A histochemical and morphometrical investigation of normal muscle. J Anat 1983, 137(Pt 1):109-126.

19. Goodale HD: A study of the inheritance of body weight in the albino mouse by selection. J Hered 1938, 29:101-112

20. MacArthur JW: Am Nat 1944, 78(775):142-157.

21. Carroll AM, Palmer AA, Lionikas A: QTL Analysis of Type I and Type IIA Fibers in Soleus Muscle in a Cross between LG/J and SM/J Mouse Strains. Front Genet 2011, 2:99.

22. Chen Y, Zhu J, Lum PY, Yang X, Pinto S, MacNeil DJ, Zhang C, Lamb J, Edwards S, Sieberts SK, Leonardson A, Castellini LW, Wang S, Champy MF, Zhang B, Emilsson V, Doss S, Ghazalpour A, Horvath S, Drake TA, Lusis AJ, Schadt EE: Variations in DNA elucidate molecular networks that cause disease. Nature 2008, 452(7186):429-435.

23. Tran LM, Zhang B, Zhang Z, Zhang C, Xie T, Lamb JR, Dai H, Schadt EE, Zhu $\mathrm{J}$ : Inferring causal genomic alterations in breast cancer using gene expression data. BMC Syst Biol 2011, 5:121.

24. Hardy MP, O'Neill LA: The murine IRAK2 gene encodes four alternatively spliced isoforms, two of which are inhibitory. J Biol Chem 2004, 279(26):27699-27708.

25. Zhu J, Lum PY, Lamb J, GuhaThakurta D, Edwards SW, Thieringer R, Berger JP, Wu MS, Thompson J, Sachs AB, Schadt EE: An integrative genomics approach to the reconstruction of gene networks in segregating populations. Cytogenet Genome Res 2004, 105(2-4):363-374.

26. Zhu J, Wiener MC, Zhang C, Fridman A, Minch E, Lum PY, Sachs JR, Schadt EE: Increasing the power to detect causal associations by combining genotypic and expression data in segregating populations. PLoS Comput Biol 2007, 3(4):e69.

27. Keller MP, Choi Y, Wang P, Davis DB, Rabaglia ME, Oler AT, Stapleton DS, Argmann C, Schueler KL, Edwards S, Steinberg HA, Chaibub Neto E, Kleinhanz R, Turner S, Hellerstein MK, Schadt EE, Yandell BS, Kendziorski C, Attie AD: A gene expression network model of type 2 diabetes links cell cycle regulation in islets with diabetes susceptibility. Genome Res 2008, 18(5):706-716

28. Farber CR, van Nas A, Ghazalpour A, Aten JE, Doss S, Sos B, Schadt EE, Ingram-Drake L, Davis RC, Horvath S, Smith DJ, Drake TA, Lusis AJ: An integrative genetics approach to identify candidate genes regulating BMD: combining linkage, gene expression, and association. J Bone Miner Res 2009, 24(1):105-116.

29. Wang S, Yehya N, Schadt EE, Wang H, Drake TA, Lusis AJ: Genetic and genomic analysis of a fat mass trait with complex inheritance reveals marked sex specificity. PLoS Genet 2006, 2(2):e15.

30. Derry JM, Zhong H, Molony C, MacNeil D, Guhathakurta D, Zhang B, Mudgett J, Small K, El Fertak L, Guimond A, Selloum M, Zhao W, Champy MF, Monassier L, Vogt T, Cully D, Kasarskis A, Schadt EE: Identification of genes and networks driving cardiovascular and metabolic phenotypes in a mouse F2 intercross. PLoS One 2010, 5(12):e14319.

31. Zhu J, Zhang B, Smith EN, Drees B, Brem RB, Kruglyak L, Bumgarner RE, Schadt EE: Integrating large-scale functional genomic data to dissect the complexity of yeast regulatory networks. Nat Genet 2008, 40(7):854-861.

32. Huang DW, Sherman BT, Lempicki RA: Systematic and integrative analysis of large gene lists using DAVID bioinformatics resources. Nat Protoc 2009, 4(1):44-57.

33. Narkar VA, Downes M, Yu RT, Embler E, Wang YX, Banayo E, Mihaylova MM, Nelson MC, Zou Y, Juguilon $H$, Kang H, Shaw RJ, Evans RM: AMPK and PPARdelta agonists are exercise mimetics. Cell 2008, 134(3):405-415.

34. Narkar VA, Fan W, Downes M, Yu RT, Jonker JW, Alaynick WA, Banayo E, Karunasiri MS, Lorca S, Evans RM: Exercise and PGC-1alpha-independent synchronization of type I muscle metabolism and vasculature by ERRgamma. Cell Metab 2011, 13(3):283-293.
35. Mazzatti DJ, Smith MA, Oita RC, Lim FL, White AJ, Reid MB: Muscle unloading-induced metabolic remodeling is associated with acute alterations in PPARdelta and UCP-3 expression. Physiol Genomics 2008, 34(2):149-161

36. Yang X, Schadt EE, Wang S, Wang H, Arnold AP, Ingram-Drake L, Drake TA, Lusis AJ: Tissue-specific expression and regulation of sexually dimorphic genes in mice. Genome Res 2006, 16(8):995-1004.

37. Bottomly D, Walter NA, Hunter JE, Darakjian P, Kawane S, Buck KJ, Searles RP, Mooney M, McWeeney SK, Hitzemann R: Evaluating gene expression in C57BL/6J and DBA/2J mouse striatum using RNA-Seq and microarrays. PLoS One 2011, 6(3):e17820.

38. Trapnell C, Pachter L, Salzberg SL: TopHat: discovering splice junctions with RNA-Seq. Bioinformatics 2009, 25(9):1105-1111.

39. Allen DL, Harrison BC, Maass A, Bell ML, Byrnes WC, Leinwand LA: Cardiac and skeletal muscle adaptations to voluntary wheel running in the mouse. J App/ Physio/ 2001, 90(5):1900-1908.

40. Morton NM, Nelson YB, Michailidou Z, Di Rollo EM, Ramage L, Hadoke PW, Seckl JR, Bunger L, Horvat S, Kenyon CJ, Dunbar DR: A stratified transcriptomics analysis of polygenic fat and lean mouse adipose tissues identifies novel candidate obesity genes. PLoS One 2011, 6(9):e23944.

41. Jones JM, Albin RL, Feldman EL, Simin K, Schuster TG, Dunnick WA, Collins JT, Chrisp CE, Taylor BA, Meisler MH: Mnd2: a New Mouse Model of Inherited Motor Neuron Disease. Genomics 1993, 16(3):669-677.

42. Jones JM, Datta P, Srinivasula SM, Ji W, Gupta S, Zhang Z, Davies E, Hajnoczky G, Saunders TL, Van Keuren ML, Fernandes-Alnemri T, Meisler MH, Alnemri ES: Loss of Omi mitochondrial protease activity causes the neuromuscular disorder of mnd2 mutant mice. Nature 2003, 425(6959):721-727.

43. Strauss KM, Martins LM, Plun-Favreau H, Marx FP, Kautzmann S, Berg D, Gasser T, Wszolek Z, Muller T, Bornemann A, Wolburg H, Downward J, Riess $O$, Schulz JB, Kruger R: Loss of function mutations in the gene encoding Omi/HtrA2 in Parkinson's disease. Hum Mol Genet 2005, 14(15):2099-2111.

44. Guttman M, Amit I, Garber M, French C, Lin MF, Feldser D, Huarte M, Zuk O, Carey BW, Cassady JP, Cabili MN, Jaenisch R, Mikkelsen TS, Jacks T, Hacohen N, Bernstein BE, Kellis M, Regev A, Rinn $J$, Lander ES: Chromatin signature reveals over a thousand highly conserved large non-coding RNAs in mammals. Nature 2009, 458(7235):223-227.

45. Sotomaru Y, Katsuzawa Y, Hatada I, Obata Y, Sasaki H, Kono T: Unregulated expression of the imprinted genes $\mathrm{H} 19$ and Igf2 $\mathrm{r}$ in mouse uniparental fetuses. J Biol Chem 2002, 277(14):12474-12478.

46. Rinn JL, Kertesz M, Wang JK, Squazzo SL, Xu X, Brugmann SA, Goodnough LH, Helms JA, Farnham PJ, Segal E, Chang HY: Functional demarcation of active and silent chromatin domains in human HOX loci by noncoding RNAs. Cell 2007, 129(7):1311-1323.

47. Cai D, Frantz JD, Tawa NE Jr, Melendez PA, Oh BC, Lidov HG, Hasselgren PO, Frontera WR, Lee J, Glass DJ, Shoelson SE: IKKbeta/NF-kappaB activation causes severe muscle wasting in mice. Cell 2004, 119(2):285-298.

48. Motoike T, Markham DW, Rossant J, Sato TN: Evidence for novel fate of Flk1+ progenitor: contribution to muscle lineage. Genesis 2003, 35(3):153-159.

49. Gavin TP, Drew JL, Kubik CJ, Pofahl WE, Hickner RC: Acute resistance exercise increases skeletal muscle angiogenic growth factor expression. Acta Physiol (Oxf) 2007, 191(2):139-146.

50. Luo G, Ducy P, McKee MD, Pinero GJ, Loyer E, Behringer RR, Karsenty G: Spontaneous calcification of arteries and cartilage in mice lacking matrix GLA protein. Nature 1997, 386(6620):78-81.

51. Keutel J, Jorgensen G, Gabriel P: A new autosomal-recessive hereditary syndrome. Multiple peripheral pulmonary stenosis, brachytelephalangia, inner-ear deafness, ossification or calcification of cartilages. Dtsch Med Wochenschr 1971, 96(43):1676-1681. passim.

52. Sasaki Y, Nagai K, Nagata Y, Doronbekov K, Nishimura S, Yoshioka S, Fujita T, Shiga K, Miyake T, Taniguchi Y, Yamada T: Exploration of genes showing intramuscular fat deposition-associated expression changes in musculus longissimus muscle. Anim Genet 2006, 37(1):40-46.

53. Lu C, Kasik J, Stephan DA, Yang S, Sperling MA, Menon RK: Grtp1, a novel gene regulated by growth hormone. Endocrinology 2001, 142(10):4568-4571.

54. Pajalunga D, Tognozzi D, Tiainen M, D'Angelo M, Ferrantelli F, Helin $K$, Sacchi A, Crescenzi M: E2F activates late-G1 events but cannot replace $\mathrm{E} 1 \mathrm{~A}$ in inducing $\mathrm{S}$ phase in terminally differentiated skeletal muscle cells. Oncogene 1999, 18(36):5054-5062.

55. Anders S, Huber W: Differential expression analysis for sequence count data. Genome Biol 2010, 11(10):R106. 
56. Hardcastle TJ, Kelly KA: baySeq: empirical Bayesian methods for identifying differential expression in sequence count data. $B M C$ Bioinforma 2010, 11:422.

57. Li H, Handsaker B, Wysoker A, Fennell T, Ruan J, Homer N, Marth G, Abecasis G, Durbin R: 1000 Genome Project Data Processing Subgroup: The Sequence Alignment/Map format and SAMtools. Bioinformatics 2009, 25(16):2078-2079.

58. Deng X: SeqGene: a comprehensive software solution for mining exomeand transcriptome- sequencing data. BMC Bioinforma 2011, 12:267.

59. Anders $S$, Reyes $A$, Huber W: Detecting differential usage of exons from RNA-Seq data. Genome Res 2012, 10:2008-17.

60. Ramensky V, Bork P, Sunyaev S: Human non-synonymous SNPs: server and survey. Nucleic Acids Res 2002, 30(17):3894-3900.

61. Ratkevicius A, Carroll AM, Kilikevicius A, Venckunas T, McDermott KT, Gray SR, Wackerhage H, Lionikas A: H55N polymorphism as a likely cause of variation in citrate synthase activity of mouse skeletal muscle. Physiological Genomics 2010, 42 A(2):96-102.

doi:10.1186/1471-2164-13-592

Cite this article as: Lionikas et al.: Resolving candidate genes of mouse skeletal muscle QTL via RNA-Seq and expression network analyses. BMC Genomics 2012 13:592.

\section{Submit your next manuscript to BioMed Central and take full advantage of:}

- Convenient online submission

- Thorough peer review

- No space constraints or color figure charges

- Immediate publication on acceptance

- Inclusion in PubMed, CAS, Scopus and Google Scholar

- Research which is freely available for redistribution 